\title{
Editorial
}

\section{What's in a Name?}

What's in a name? That which we call a rose

By any other name would smell as sweet.

So Romeo would, were he not Romeo call'd,

Retain that dear perfection which he owes

Without that title.

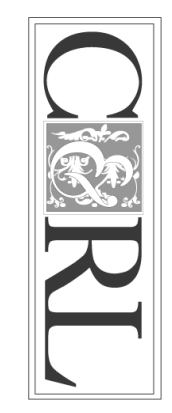

William Shakespeare,

The Tragedy of Romeo and Juliet, Act II, Scene II

In one of Shakespeare's most popular plays, Juliet makes a passionate plea for her Romeo to be judged by his character, which she esteems, rather than by his name, which her family abhors. Names, and what they represent, have been much in our thoughts, of late, as another institution of higher education considers adopting a new one for the academic unit responsible for the pre-service and continuing professional education of librarians; one that, as has often been the case, abandons the use of the word "library."

Over the past decade, passionate debates over "the L word" in library and information science (LIS) programs have played out at institutions including Rutgers University (School of Communication and Information), Indiana University (School of Informatics and Computing), San Jose State University (School of Information), and, most recently, The Pratt Institute (School of Information) and the University of Illinois at UrbanaChampaign (School of Information Sciences, as currently proposed). Advocates for these changes have suggested that the new names are more inclusive of the range of professional roles and responsibilities for which these schools provide an education and that little is lost in terms of the ability of these schools and their faculty to advocate for a forward-looking vision of the future for libraries and librarians.

We disagree. We believe there is something in a name, and that it is time to consider what we might do to explore what that something might be through research into professional education, changes in the faculty workforce, and the values that students and in-service professionals embrace when they choose to study and pursue a career in libraries and librarianship

Let us begin by acknowledging, as Juliet does, that names, by themselves, do not define a thing. Romeo's virtues (as well as his flaws) stem from his character and from his response to a difficult set of circumstances, rather than from something inherent in a particular surname. But, given the centrality of classification to our field, we would be remiss if we did not also acknowledge the importance of naming (and re-naming) a person, place, or thing. Naming and re-naming, especially when done consciously and with intent, almost always carries meaning. That meaning may not reside solely in the name, itself, but also in the values those doing the naming hope to reinforce through the process.

Consider Michael Buckland's take on Patrick Wilson's seminal work on bibliographic control, Two Kinds of Power (1968):

The challenge is to create descriptions that will enable those to be served to identify and select the best documentary means to whatever their ends may be. By definition, the descriptions used by librarians are for future use. This requires the librarian to think about likely needs and to describe (name) in a forward-looking 
way. To do this the librarians constructs, consciously or not, some mental narrative about future use, some story in which the document in hand would be relevant to future needs. It is not simply a matter of what the document is about, but of where it might be useful in an imagined future. Familiarity with the community and its purposes, ways of thinking, and terminology is an important requirement for the effective librarian. ${ }^{1}$

Taking our lead from Buckland and Wilson, we must ask: what do these programs' name changes say about their "mental narrative about future use"? Who are their communities? What are their imagined futures? Specifically, what future do they imagine they are helping to shape for professionals in libraries, archives, and other cultural heritage organizations?

The last big rounds of program name changes came in the late 1990s and again a decade ago. In defending those changes, the University of Oklahoma's Danny P. Wallace dismissed conflict between faculty and practitioners as "a question of semantics." Both in 2002 and 2009, Wallace argued (correctly) that academic units exist within larger institutional contexts and that the naming of a department, college, or school, is often the result of unique institutional challenges and opportunities. ${ }^{2}$ The University of Arizona's Carla J. Stoffle put forward a similar argument in suggesting that the concerns raised by practitioners about the conduct of their own professional education were simply the result of a "misunderstanding." 3 The "fundamental question," Wallace and his co-author, Connie Van Fleet, said, is not whether a unit responsible for educating future librarians has the word "library" in its name, but whether it continues to draw the interest of would-be librarians (and other library professionals) and whether its graduates remain "capable of entering professional careers in libraries." 4

Both of us have written previously about the changing nature of those careers and appreciate the moving target this benchmark provides. ${ }^{5}$ That moving target, as well as the evolution of the complementary and interdisciplinary areas of inquiry that make up a thoughtful approach to "information studies," was noted by the University of Pittsburgh's Ronald L. Larsen in his 2007 description of the iSchools organization. ${ }^{6}$ But, the key data point on which Wallace depended to close his argument that practitioner concern about the loss of "the L word" was unfounded was the growth throughout the 1990s and early 2000s in enrollment in ALA-accredited programs, regardless of their nomenclature. Even if the growth in enrollments, alone, was sufficient argument against any concern with the trend to embrace "information" over "libraries" in naming our field, it is an argument that no longer obtains, as enrollment in these programs has seen a steep decline in recent years. ${ }^{7}$ That decline is one context within which the future of professional education must be considered, and not only in LIS; consider the situation in legal education, which has seen a similar decline in program enrollments and similar concerns about the market for recent graduates. ${ }^{8}$

Another context to consider in higher education is the growth (and role) of contingent faculty in the academy. The American Association of University Professors (AAUP) has documented the growth of the contingent faculty as an aspect of broader changes in the faculty workforce, as well as the potential challenges these changes present to faculty engagement in curricular decisions, governance activities, etc. ${ }^{9}$ In a field where practitioners make up a significant percentage of the faculty providing direct instruction in LIS courses, as well as the majority of the field experiences that students routinely report as a critical component in their preparation for a successful entry into the professional workforce, the question of the degree to which practitioners (or faculty with a commitment to professional practice) are represented in the composition of the tenure-system faculty is an important one. ${ }^{10}$ 
Finally, there are questions regarding the commitment found in LIS programs to promoting forward-looking research and practice in the library field(s). "Commitment" may be measured in many ways, but, for example, are experts on an array of issues relevant to libraries and librarians included among the tenure-system faculty? Are issues related to libraries and librarianship represented among the research areas highlighted by the academic unit? Are there meaningful and sustainable efforts in place to promote collaboration between the academic unit responsible for LIS education and the libraries, archives, and other cultural heritage organizations present on campus or in the local community? Does the academic unit promote ongoing and meaningful collaboration and consultation with leaders in the field through advisory committees, curriculum reform, access to field experience, and shared approaches to promoting professional placement? Do practitioners serving as members of the contingent faculty have the opportunity for meaningful engagement in governance, curriculum review, or helping to shape the vision for the future of the field and its professional education? How do students, whether prospective, currently enrolled, or alumni, perceive the degree to which the academic unit reflects the professional values they wish to adopt in their work? And, finally, to what degree do any of these questions inform the work of accreditation teams charged to work with faculty, students, alumni, and other stakeholders in a process designed to ensure engagement between the academy and the profession(s)?

These are important questions, not just for LIS education, but for any academic unit with a mandate to collaborate with practitioners to prepare the next generation of professionals in a given field. We might ask similar questions not only of Law, but also of Journalism, Education, Social Work, Health Sciences, and Business, as all share not only that core mandate, but also the imperative to adapt to changing landscapes in higher education and the workplace. These are questions that can be explored through research into the composition of the faculty of our professional education programs, as well as the structures of curriculum design, shared governance, and practitioner engagement (which may also be alumni engagement). These are questions that can be explored through research not only into the student population of our pre-service professional education programs, but also into the ongoing role of practitioners as students (and teachers) in continuing professional education. Indeed, inquiry into the factors promoting meaningful, sustainable, and productive collaboration between LIS faculty and LIS practitioners in supporting professional education across the arc of a career that will be spent in organizations in the midst of fundamental change represents some of the most important questions we might explore.

Names are important, but the reality is that it is concern about meaningful engagement with the values and needs of our changing professions that underpins expressions of consternation among practitioners over the presence or absence of "the L word" in the names of programs upon which we depend for the education of our colleagues. There are several iSchools where evidence of meaningful engagement with the field exists, and where the "imagined future" for libraries is an exciting one. Examples include (but are not limited to) Drexel University's College of Computing and Informatics and its Center for the Study of Libraries, Information, and Society, and Syracuse University's School of Information Studies with its teaching and research focus in areas such as information literacy, library assessment, and "new librarianship." The questions we have posed above represent an initial attempt to articulate areas of inquiry that might help to illuminate the dimensions of that engagement and to articulate the ways in which decisions about the recruitment of students, allocation of faculty lines, composition of tenure-system and contingent faculty and their engagement in governance activities, and support for "engagement agendas" in teaching, learning, 
and scholarship take us far beyond earlier discussions of data points such as program enrollment or counting the number of academic units that do, or do not, include the word "library" in their names.

Research such as this is an important part of understanding the nuances that distinguish different approaches to shaping the future for library and information science education, both pre-service and in-service. Such research may show us that there are schools that have dropped "library" from their names but demonstrate a strong commitment to libraries and librarianship in manners consistent with their unique organizational contexts, just as it might uncover "L-school" programs that can demonstrate such commitment in name only. But until we-our community of scholars and practitioners - do this work and find these answers, we will remain concerned that the "imagined future" conjured through the re-naming of LIS programs is one that diminishes both the perceived value of libraries and the professional values that have long been at the heart of recruiting colleagues into the professions of librarianship.

Carol Tilley

University of Illinois at Urbana-Champaign

Scott Walter

DePaul University

\section{Notes}

1. Michael Buckland, "Naming in the Library: Marks, Meanings, and Machines," in Nominalization, Nomination and Naming in Texts, eds. Christian Todenhagen and Wolfgang Thiele (Tübingen, Germany: Stauffenburg Verlag, 2007), 253.

2. Connie Van Fleet and Danny P. Wallace, "The I-Word: Semantics and Substance in Library and Information Studies Education," Reference \& User Services Quarterly 42 (2002): 104-109; Danny P. Wallace, "The iSchools, Education for Librarianship, and the Voice of Doom and Gloom," Journal of Academic Librarianship 35 (2009): 405-409.

3. Carla J. Stoffle and Kim Leeder, "Practitioners and Library Education: A Crisis of Understanding," Journal of Education for Library and Information Science 46 (2005): 312-319.

4. Van Fleet and Wallace, "The I-Word," 108.

5. Danny Callison and Carol Tilley, "Descriptive Impressions of the Library and Information Science Education Evolution of 1988-1998 as Reflected in Job Announcements, ALISE Descriptors, and New Course Titles," Journal of Education for Library and Information Science 42 (2001): 181-199; Scott Walter, “The Library as Ecosystem," Library Journal 133 (October 1, 2008): 28-30, accessed December 8, 2015. http://lj.libraryjournal.com/2008/10/academic-libraries/the-libraryas-ecosystem/; Scott Walter and Karen Williams, eds., The Expert Library: Staffing, Sustaining, and Advancing the Academic Library in the $21^{\text {st }}$ Century (Chicago: Association of College \& Research Libraries, 2010).

6. Ronald L. Larsen, Letter to the editor, Library Journal 132 (October 15, 2007): 11.

7. In Fall 2010, the American Library Association's Office of Accreditation reported 20,019 students enrolled in ALA-accredited Master's degree programs; by Fall 2014, that number had dropped to $15,197(-24 \%)$. Annual reports of student enrollment are available in Prism, the newsletter of the Office of Accreditation, at (http://www.ala.org/offices/accreditation/prp/prism/ prism_current).

8. Natalie Kitroeff, "Law School Applications Set to Hit 15-Year Low," Bloomberg Business (March 19, 2015), accessed December 12, 2015, http://www.bloomberg.com/news/articles/2015-03-19/law-school-applications-will-hit-their-lowest-point-in-15-years.

9. "Resources on Contingent Appointments," American Association of University Professors, accessed December 8, 2015, http://www.aaup.org/issues/contingency.

10. According to the Association of Library and Information Science Education (ALISE) Statistical Report, there were 959 full-time, tenure-system faculty in member programs as of January 2015, 128 full-time, non-tenure-system faculty, and 840 part-time faculty. In addition to this diversity in appointment type, LIS programs demonstrate a diversity in background among 
full-time faculty, with more than one-third holding doctoral degrees in fields outside LIS. See: "ALISE Statistical Reports and Database," Association for Library and Information Science Education, accessed December 13, 2015, http://www.alise.org/statistical-reports-2. On the value of field experiences as a component of professional education in LIS, see, for example: Susan E. Searing and Scott Walter, "Is Experience the Best Teacher?: Field Experience and Student Learning in LIS Education Programs," in Proceedings of the 2012 Library Assessment Conference: Building Effective, Sustainable, Practical Assessment, October 29-31, 2012, Charlottesville, VA, eds. Steve Hiller, et al. (Washington, DC: Association of Research Libraries, 2013), 207-219, accessed December 15, 2015, http://libraryassessment.org/bm doc/proceedings-lac-2012.pdf.

$* * *$

The editorial board of College $\mathcal{E}$ Research Libraries mourns the loss of our colleague, Richard Fyffe, Samuel R. and Marie-Louise Rosenthal Librarian of the College at Grinnell College, who passed away on November 5, 2015. Richard was a valued friend who had served on the editorial board since 2011. Richard's work in the area of scholarly communications appeared in journals such as Library Resources \& Technical Services, Journal of Library Administration, and Against the Grain, and his work with CERL editor Scott Walter was described in a 2005 CERL News article, "Building a New Future: 'Preparing Future Faculty' and 'Responsible Conduct of Research' Programs as a Venue for Scholarly Communications Discussions” (http://bit.ly/1Pyhy1Q). Under his leadership, Grinnell College was recognized with the ACRL "Excellence in Academic Libraries" award in 2011. He will be missed. 